\title{
Validation of the HPLC-PDA method for detection of eluxadoline and rifaximin in rat plasma and application in a pharmacokinetic study
}

Vijendar Reddy Karla, Babji Palakeeti, M. Raghasudha and Raghu Chitta* (1)

\begin{abstract}
Background: A precise, simple, accurate, and quick HPLC-PDA method for the determination of eluxadoline and rifaximin in rat plasma was developed and validated in this study. In this method, Loperamide hydrochloride was used as the internal standard and plasma samples were prepared using a liquid-liquid extraction technique for which acetonitrile was a solvent. An Agilent Symmetry C8 column ( $5 \mu \mathrm{m}, 250 \mathrm{~mm} \times 4.6 \mathrm{~mm})$ at $283 \mathrm{~nm}$ and isocratic elution using HPLC grade acetonitrile and $7 \mathrm{mM}$ TEA $(\mathrm{pH} 2.5)$ with a ratio of $(40: 60 \mathrm{v} / \mathrm{v})$ was used as a mobile phase and the flow rate employed was $1 \mathrm{~mL} \mathrm{~min}^{-1}$. A satisfactory chromatographic separation was accomplished.

Results: An HPLC-PDA method for the determination of eluxadoline and rifaximin with retention times of 3.06 and $7.82 \mathrm{~min}$, respectively, was developed. The calibration curves appear linear for both eluxadoline and rifaximin in the range of 5-200 $\mathrm{ng} \mathrm{mL}^{-1}$ and 10-400 $\mathrm{ng} \mathrm{mL}^{-1}$, and the corresponding correlation coefficient values were found to be 0.9999 and 0.9998 respectively. Lower limits of quantification (LLOQ) for eluxadoline and rifaximin were evaluated to be $5.0 \mathrm{ng} \mathrm{mL}^{-1}$ and $10.0 \mathrm{ng} \mathrm{mL}^{-1}$, respectively. The accuracy and precision results in all validation experiments were within the acceptance limits of FDA guidelines.

Conclusion: The developed HPLC-PDA approach was fully validated to meet the USFDA guidelines for bioanalytical method validation in terms of precision, accuracy, and stability. The presented approach could be beneficial for the determination of ELX and RFX in rat plasma, according to validation parameters. This is one of the efficient method to study the pharmacokinetics of ELX and RFX in rats.
\end{abstract}

Keywords: Eluxadoline, Rifaximin, HPLC-PDA, Pharmacokinetics, Rat plasma

${ }^{*}$ Correspondence: raghuchitta@nitw.ac.in

Department of Chemistry, National Institute of Technology Warangal,

Hanamkonda, Telangana 506004, India 


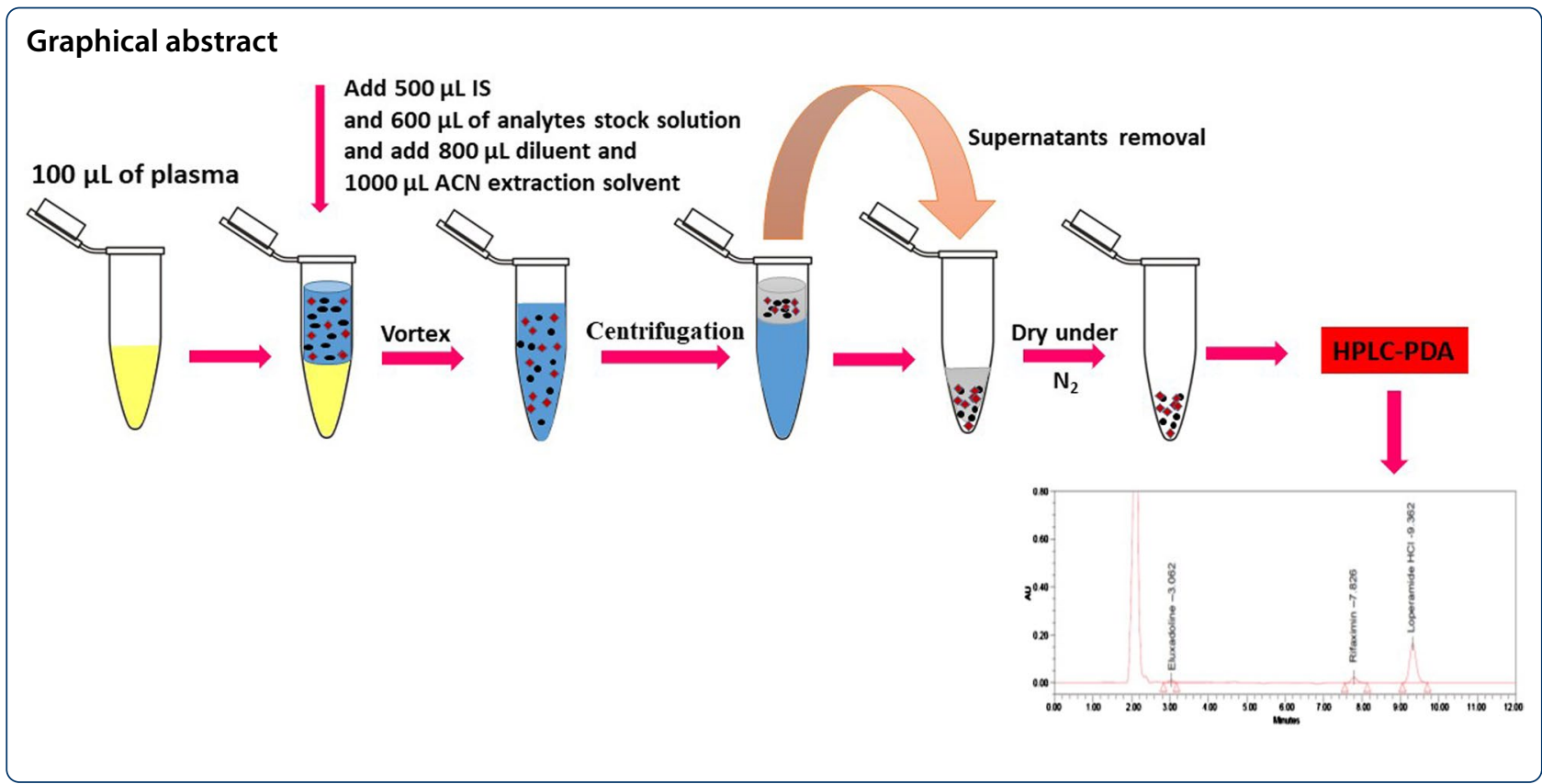

\section{Background}

Eluxadoline (ELX), is chemically designed as 5-(\{[(2S)2-amino-3-(4-carbamoyl-2,6-dimethylphenyl)propanoyl][(1S)-1-(4-phenyl-1H-imidazoi-2-yl)ethyl]amino\} methyl)-2-methoxybenzoic acid) [1]. Eluxadoline is a new oral active medication having opioid effects ( $\mu$ - and $\mathrm{k}$-opioid receptor agonist and antagonist) and is used to treat IBS with diarrhoea [2]. Due to low gastrointestinal permeability and important presystemic metabolism, eluxadoline has a low oral bioavailability of less than $1 \%$ $[3,4]$. After oral administration of $100 \mathrm{mg}$ of eluxadoline, the area under the plasma concentration-time profile (AUC) was 11-22 $\mathrm{ng} \mathrm{h} \mathrm{mL} \mathrm{h}^{-1}$ and the peak plasma concentration $\left(C_{\max }\right)$ was $2-4 \mathrm{ng} \mathrm{mL}^{-1}$ at $1.5-2.0 \mathrm{~h}$. It is $81 \%$ bound to plasma proteins, with a half-life of 3.7-6.0 h [5]. The safety and efficacy of eluxadoline in patients with irritable bowel syndrome (IBS-D) with diarrhoea were studied in two randomized, double-blind, placebocontrolled phase 3 studies (TARGET 1 and 2), and a unique phase 3 retreatment trial (TARGET 3) [6-9]. In 2015, FDA approved Rifaximin (RFX) for the treatment of the gastrointestinal disorder (IBS-D) in adults. It is chemically designated as $(2 S, 16 Z, 18 E, 20 S, 21 S, 22 R, 23$ $R, 24 R, 25 S, 26 R, 27 S, 28 E$ )-25-(Acetyloxy)-5,6,21,23-tetra hydroxy-27-methoxy-2,4,11,16,20,22,24,26-octamethyl2,7-(epoxypentadeca[1,11,13] trienimino)benzofuro[4,5e]pyrido[1,2-a]benzimidazole-1,15(2H)-dione.

Currently, there are few literature reports on the methods to determine these drugs in the biological samples. Eluxadoline has been determined in rat plasma using $\mu$-SPE followed by LC-MS/MS [10]. The LC-MS/MS technique was used to investigate the pharmacokinetics of eluxadoline in healthy South Indian male participants [11]. RP-HPLC was used to separate and identify eluxadoline and its impurities [12]. The degradation behaviour of the eluxadoline under various stress conditions followed by the identification of the degradation products by HR-MS/MS and NMR studies was reported [13]. Similarly, to determine RFX in biological matrices and pharmaceutical dosage forms, various analytical methods such as HPLC [1417], LC-MS/MS [18], LC-ESI-MS [19, 20] have been reported. Even though these techniques have attained the requisite sensitivity and application, some of them require a considerable volume of plasma, many of them adopt a tedious extraction procedure, and others are either expensive or unavailable in most laboratories. Furthermore, as per our knowledge, no analytical approach for the simultaneous determination of eluxadoline and rifaximin in rat plasma has been described till date. Whereas, the method used in the present study HPLC-PDA has numerous advantages such as good separation, high sensitivity, outstanding specificity, and low cost as compared to the methods reported earlier.

Our aim in this present research work is to develop and validate a fast HPLC-PDA method for simultaneously quantifying of ELX and RFX in rat plasma for pharmacokinetic studies. The bioanalytical method employed here has been validated as per the USFDA guidelines. Figure 1 depicts the structures of analytes. 


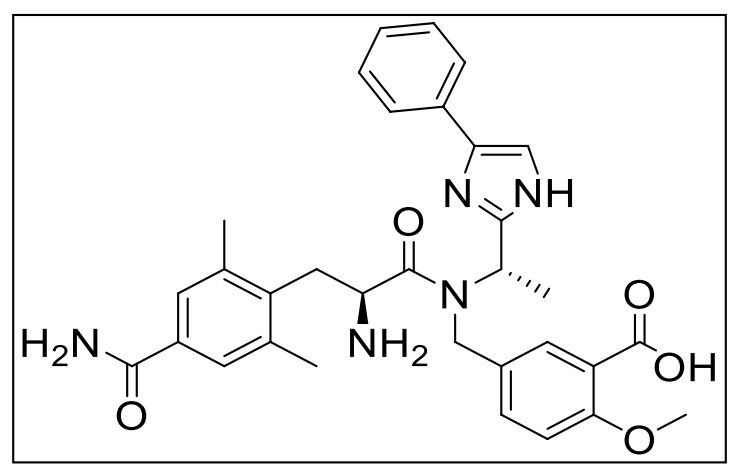

(a)

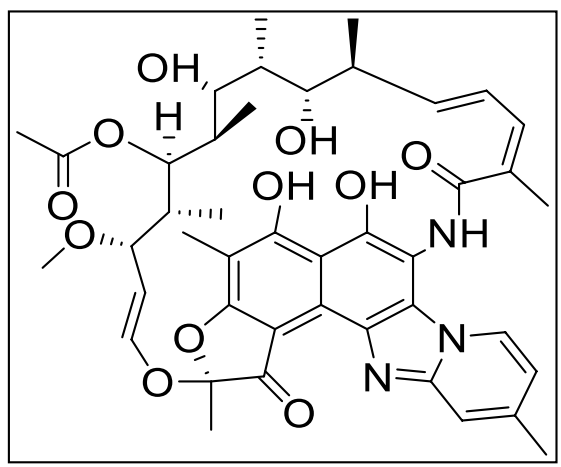

(b)

Fig. 1 Chemical structures of $\mathbf{a}$ eluxadoline, $\mathbf{b}$ rifaximin

\section{Methods}

\section{Materials and reagents}

The ELX, RFX, and loperamide hydrochloride (IS) were collected from the local manufacturing pharmaceutical industry (Hyderabad, India). Deionized water used for sample preparation was obtained from Milli $Q$ water purification system purchased from Millipore (Bangalore, India). HPLC gradient grade acetonitrile (ACN) was purchased from Merck (Mumbai, India). HPLC grade orthophosphoric acid (OPA), triethylamine (TEA) were obtained from Sigma Aldrich (Mumbai, India). In the present study, drug-free rat plasma was acquired from Bio needs Laboratory (Bangalore, India), and it was stored at $-20{ }^{\circ} \mathrm{C}$ until analysis. The centrifuge type $2-16 \mathrm{P}$ (Sigma, Zurich, Switzerland), nylon syringe filters $0.22 \mathrm{~m}$ (Millipore, India), and heparinized tubes were used to collect blood samples.

\section{Preparation of buffer solution}

$1 \mathrm{~mL}$ Triethyl amine in $1 \mathrm{~L}$ water and the $\mathrm{pH}$ was adjusted to 2.5 with orthophosphoric acid.

\section{Apparatus and chromatographic conditions}

An alliance e2695 HPLC system (Waters Corp., Milford, MA, USA) with a quaternary pump, in-line degasser, auto-injector, column compartment, and PDA detector (model-2998) was used for HPLC analysis. Empower 2 software was used to collect chromatographic data. All separation was achieved on Agilent Symmetry C8 column $(5 \mu \mathrm{m}, 250 \mathrm{~mm} \times 4.6 \mathrm{~mm})$ at room temperature. Isocratic elution with HPLC grade acetonitrile and $7 \mathrm{mM}$ TEA (pH 2.5) (40:60, v/v) at a flow rate of $1 \mathrm{~mL} \mathrm{~min}^{-1}$, an injection volume of $10 \mu \mathrm{L}$, and detection at $283 \mathrm{~nm}$ was used to determine ELX and RFX. A filter paper of $0.45 \mu \mathrm{m}$ was used to filter all the solutions and solvents (Millipore, India).

\section{Preparation of standard stock and working solutions}

Standard stock solutions were prepared by accurately weighing $10 \mathrm{mg}$ of ELX and $20 \mathrm{mg}$ of RFX and dissolving them individually in $100 \mathrm{~mL}$ of HPLC grade ACN. Stock solutions were further diluted to prepare the working solutions. The IS working solution $\left(1.5 \mathrm{ng} \mathrm{mL}^{-1}\right)$ was made by diluting the IS stock solution with the same diluent. All the solutions were stored at $4{ }^{\circ} \mathrm{C}$ in a volumetric flask and warmed to room temperature just before use.

\section{Preparation of plasma CC standards and QC samples}

Calibration curve (CC) standards of the analytes were made by spiking a suitable volume of working solutions into blank plasma and final concentrations were obtained as 10.0, 25.0, 50.0, 75.0, 100.0, 125.0, 150.0, and $200.0 \mathrm{ng} \mathrm{mL}^{-1}$ for ELX; and 20.0, 50.0, 100.0, 150.0, 200.0, 250.0, 300.0, $400.0 \mathrm{ng} \mathrm{mL} \mathrm{mL}^{-1}$ for RFX. The quality control samples for both ELX and RFX were prepared at three different concentration levels in blank plasma. In case of ELX, the lower quality control concentration (LQC) was prepared to be $50.0 \mathrm{ng} \mathrm{mL}^{-1}$, the medium (MQC) and high quality control concentration (HQC)

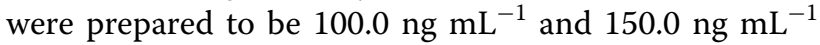
respectively. Whereas in the case of RFX the LQC was $100.0 \mathrm{ng} \mathrm{mL}^{-1}$, the MQC was $200.0 \mathrm{ng} \mathrm{mL}^{-1}$ and HQC was $300 \mathrm{ng} \mathrm{mL}{ }^{-1}$. All spiked samples were stored in a deep freezer at $-80{ }^{\circ} \mathrm{C}$.

\section{Sample preparation}

To extract analytes from the plasma, we have employed the liquid-liquid extraction method [21-23]. A plasma sample of $100 \mu \mathrm{L}$ spiked with analytes of $600 \mu \mathrm{L}$ and IS of $500 \mu \mathrm{L}$ was added to an Eppendorf tube of $5 \mathrm{~mL}$ and the mixing process has been carried out for 1 min using a vortex. $800 \mu \mathrm{L}$ of diluent was added to the samples and vortexed. After adding $1000 \mu \mathrm{L}$ of $\mathrm{ACN}$ to the tube 
and vortex for $10 \mathrm{~min}$, the mixture was centrifuged at $4500 \mathrm{rpm}$ for $20 \mathrm{~min}$ at $10{ }^{\circ} \mathrm{C}$. The supernatant solution was taken into another clean vial and dried under a nitrogen environment at $25{ }^{\circ} \mathrm{C}$. The residue was dissolved in $100 \mu \mathrm{L}$ of mobile phase and, of which, $10 \mu \mathrm{L}$ aliquot was injected into HPLC system.

\section{Method validation}

The US FDA bioanalytical method validation guidelines were used to validate the specificity, sensitivity, linearity, accuracy, precision, matrix effect, extraction recovery, and stability of the analytical method [24].

\section{Specificity}

To determine the specificity, six different samples of rat plasma and blank plasma spiked with target analytes, ELX and RFX were taken and retention times were analyzed. By analyzing the retention times of analytes and IS, no evidence of interfering substances was found under developed chromatographic conditions.

\section{Sensitivity}

The LLOQC samples were prepared and processed in six replicates to measure sensitivity, precision, and accuracy at the LLOQ level. The precision and accuracy should be within the acceptable limits of $\leq 20 \%$ and $80-120 \%$, respectively.

\section{Carry-over effects}

Carry-over was tested by injecting a blank sample of plasma immediately after the analysis of the upper limit of quantification, with acceptability criteria of $20 \%$ of the response of the analytes at the lower limit of quantification and $5 \%$ of the IS peak response.

\section{Linearity and LLOQ}

To plot calibration curves, the ratio of peak areas of analytes to the IS was plotted against the concentrations of the analytes over the range from 5 to $200 \mathrm{ng} \mathrm{mL}{ }^{-1}$ for ELX; and from 10 to $400 \mathrm{ng} \mathrm{mL}{ }^{-1}$ for RFX. The concentration of internal standard was maintained at $1.5 \mathrm{ng} \mathrm{mL} \mathrm{m}^{-1}$. The linearity was assessed using linear regression analysis. The LLOQ is defined as the lowest concentration of analytes in the calibration curve. The precision and accuracy were found to be within the acceptance criteria of $\leq 20 \%$ and $80-120 \%$, respectively.

\section{Accuracy and precision}

The determination of the accuracy and precision of this method was done by analyzing six replicates at four different QC levels: 5.0 (LLOQ), 50.0 (LQC), 100.0 (MQC), and $150.0 \mathrm{ng} \mathrm{mL}{ }^{-1}$ (HQC) for ELX and 10.0 (LLOQ), 100.0 (LQC), 200.0 (MQC) and $300.0 \mathrm{ng} \mathrm{mL}^{-1}$ (HQC) for RFX. The precision and accuracy of the method were determined through the percentage of coefficient of variation $(\% \mathrm{CV})$ and percentage recovery.

\section{Extraction recovery}

Recovery of analytes was determined by comparing with the peak areas of analytes extracted from six replicates $(n=6)$ of QC samples at LQC, MQC, and HQC levels to the equivalent areas of un-extracted analytes at the same concentrations.

\section{Matrix effect}

The matrix effect was measured by comparing the peak area of analytes spiked to blank plasma extracted samples to the clean standard solutions. Matrix effect calculated using six different sources of plasma lots at the levels of LQC and HQC. No noticeable matrix effect was observed on this method.

\section{Stability}

The stability was assessed for LQC and HQC concentrations of ELX and RFX in rat plasma, using different storage and handling conditions of samples. The benchtop stability was tested at room temperature for $6 \mathrm{~h}$. The QC samples were kept in auto-sampler vials at $10{ }^{\circ} \mathrm{C}$ for $24 \mathrm{~h}$. For long-term stability, samples were stored in a deep freezer at $-80^{\circ} \mathrm{C}$ for 28 days. Freeze-thaw stability was investigated through three freeze-thaw cycles from $80{ }^{\circ} \mathrm{C}$ to room temperature.

\section{Dilution integrity}

The effect of dilution of samples on the accuracy and precision of the method was investigated by testing the dilution integrity. To investigate the dilution integrity at a twofold dilution and the spiked samples were prepared above the ULOQ and tested in six replicates. The precision and accuracy should be within the acceptance criteria of $\leq 20 \%$ and $85-115 \%$, respectively.

\section{Application to a pharmacokinetic study}

Six healthy rats weighing approximately $200 \pm 20$ g were used in a pharmacokinetic study. An oral dose of ELX at $0.416 \mathrm{mg} / \mathrm{kg}$ and RFX at $0.832 \mathrm{mg} / \mathrm{kg}$ was given to each rat. The rats were fasted for $12 \mathrm{~h}$ before administering the drugs and had access to water during the experiment. The blood samples were collected at $0.25,0.5,0.75$, $1.0,1.5,2.0,3.0,4.0,5.0,6.0 \mathrm{~h}$ after the administration of drugs. Blood samples were taken in heparin-containing tubes and centrifuged at $4500 \mathrm{rpm}$ for $10 \mathrm{~min}$ at $8{ }^{\circ} \mathrm{C}$. The plasma samples were then refrigerated at $-80{ }^{\circ} \mathrm{C}$ until they were analyzed. WinNonlin software was used to determine pharmacokinetic parameters. 


\section{Results}

\section{HPLC method development and optimization}

The present study aimed to develop an HPLC-PDA method for simultaneously quantifying ELX and RFX in rat plasma samples and validate the method. A systematic approach was employed to develop and optimize method during the optimization process of the experimental conditions. During the study, the chromatographic conditions that are to be optimized are mobile phase selection, type of column, and flow rate to achieve optimal separation and resolution from endogenous plasma components and eventually, obtain sharp peak form and enough peak responsivity. The separation was performed using RP-HPLC with a variety of mobile phase combinations including organic modifiers such as methanol and acetonitrile in various concentrations, as well as buffers containing orthophosphoric acid and triethylamine of varying strength on Symmetry RP18, $150 \mathrm{~mm} \times 4.6 \mathrm{~mm}$, $3.5 \mu \mathrm{m}$; X-Bridge phenyl $150 \times 4.6 \mathrm{~mm}, 3.5 \mu \mathrm{m}$; Agilent Symmetry C8, $250 \mathrm{~mm} \times 4.6 \mathrm{~mm}, 5 \mu \mathrm{m}$ columns.

After several trials, the mobile phase containing HPLC grade acetonitrile and $7 \mathrm{mM}$ TEA in water $(\mathrm{pH}$ 2.5) $(40: 60, \mathrm{v} / \mathrm{v})$ was selected. We have found excellent responses from ELX and RFX with no potential interference from endogenous substances when the flow rate was

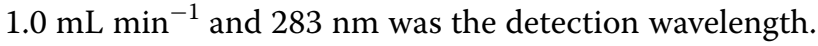
Hence, the above-mentioned conditions were selected for analysis. The retention time was found to be 3.06 and 7.82 min under the selected conditions, and the total run time was $12 \mathrm{~min}$.

\section{Method validation \\ Specificity}

To evaluate the specificity of the method, six drug-free plasma samples from different sources were selected. To assess the interferences, the peak responses of the blank plasma and plasma samples spiked with the analytes and internal standard (IS) were compared. No interference was observed at the retention of analytes and IS from matrix endogenous components, as indicated in Fig. 2.

\section{Sensitivity}

The LLOQs for ELX and RFX was found to be $5.0 \mathrm{ng} \mathrm{mL}{ }^{-1}$ and $10.0 \mathrm{ng} \mathrm{mL}^{-1}$, respectively. At this concentration, precision and accuracy results were found to be $0.48,100.4 \%$ for ELX, and 1.37, 101.9\%, respectively. The retention time of ELX, RFX, and IS were 3.06, 7.82, and $9.36 \mathrm{~min}$, respectively. The chromatogram of analytes at LLOQ is shown in Fig. 3.

\section{Carry-over effects}

Analysis of blank samples of plasma after injection of ULOQ samples revealed no peaks at the retention times of both analytes and IS, indicating that the described approach has no carryover effect.

\section{Linearity and LLOQ}

Linearity was assessed by preparing eight calibration standards in rat plasma with concentrations ranging from 5 to $200 \mathrm{ng} \mathrm{mL}{ }^{-1}$ for ELX; and $10-400 \mathrm{ng} \mathrm{mL}^{-1}$ for RFX. The internal standard concentration was maintained at $1.5 \mathrm{ng} \mathrm{mL}^{-1}$. The ratio of peak areas of analytes to the IS plotted against concentrations of analytes to plot calibration curves. The linearity of analytes is determined by linear regression analysis. The calibration curves were constructed and found to be linear with good correlations coefficient $\left(r^{2}\right)$ of 0.9999 and 0.9998 for ELX and RFX, respectively. The LLOQ was determined with tolerable accuracy and precision $(\leq 20 \%)$. The LLOQ for ELX and RFX were found to be 10.0 and $5.0 \mathrm{ng} \mathrm{mL}{ }^{-1}$ respectively. These results are shown in Additional file 1: Table S1. Additional file 1: Fig. S1 shows the represented chromatogram of analytes at LLOQ.

\section{Accuracy and precision}

The intra- and inter-day accuracy and precision of the method were determined by analyzing six replicates at four concentrations of QC samples (LLOQ, LQC, MQC, and HQC). The accuracy and precision were calculated and depicted as percentage of recovery and percentage of coefficient of variation (\% CV) respectively. The acceptance criteria for accuracy within a range of $85-115 \%$ and the precision within $15 \%$ of the $\mathrm{CV}$. The results of accuracy and precision were tabulated in Table 1.

\section{Extraction recovery}

Analytes recovery was calculated by comparing the peak areas of extracted analytes from six replicate $(n=6)$ QC samples at three concentration levels (Lower, Medium, High QC) with the corresponding areas of unextracted analytes at the equivalent concentrations. The extraction recoveries for the three QC levels (Lower, Medium, High QC) for ELX were $97.0 \%, 91.5 \%$, and 93.8\%, respectively. The recoveries for RFX were $98.3 \%, 91.6 \%$ and $95.3 \%$, respectively. The obtained results are tabulated in Table 2.

\section{Matrix effect}

The matrix effect was investigated using six dissimilar plasma lots at two different QC concentrations by comparing analytes peak area spiked to extracted blank plasma samples to plain standard solutions at the 

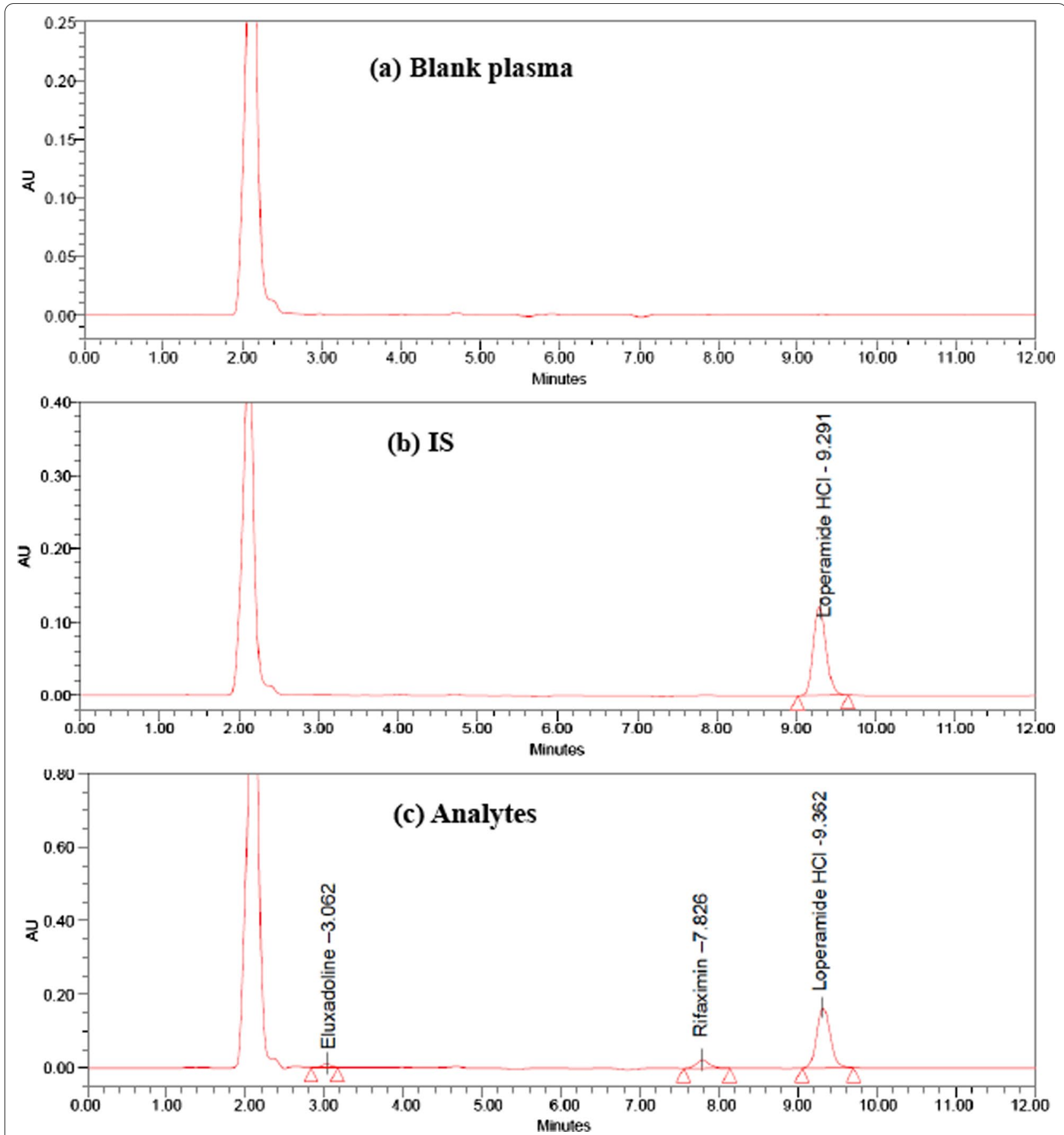

Fig. 2 Representative chromatograms of a blank plasma, b IS and c analytes at LLOQ $5.0 \mathrm{ng} / \mathrm{mL}$ and $10.0 \mathrm{ng} / \mathrm{mL}$ of ELX and RFX, respectively

identical concentration (Lower and Higher QC). The percentage of coefficient of variation (\% CV) is within the acceptable range. No matrix effect was observed in rat plasma. The results are tabulated in Table 3.
Stability

The stability of ELX and RFX in plasma samples was studied under different storage conditions at LQC and HQC levels in six replicates. At the benchtop stability conditions, analytes were stable up to $6 \mathrm{~h}$ when stored at room temperature. In auto-sampler, the analytes in the 

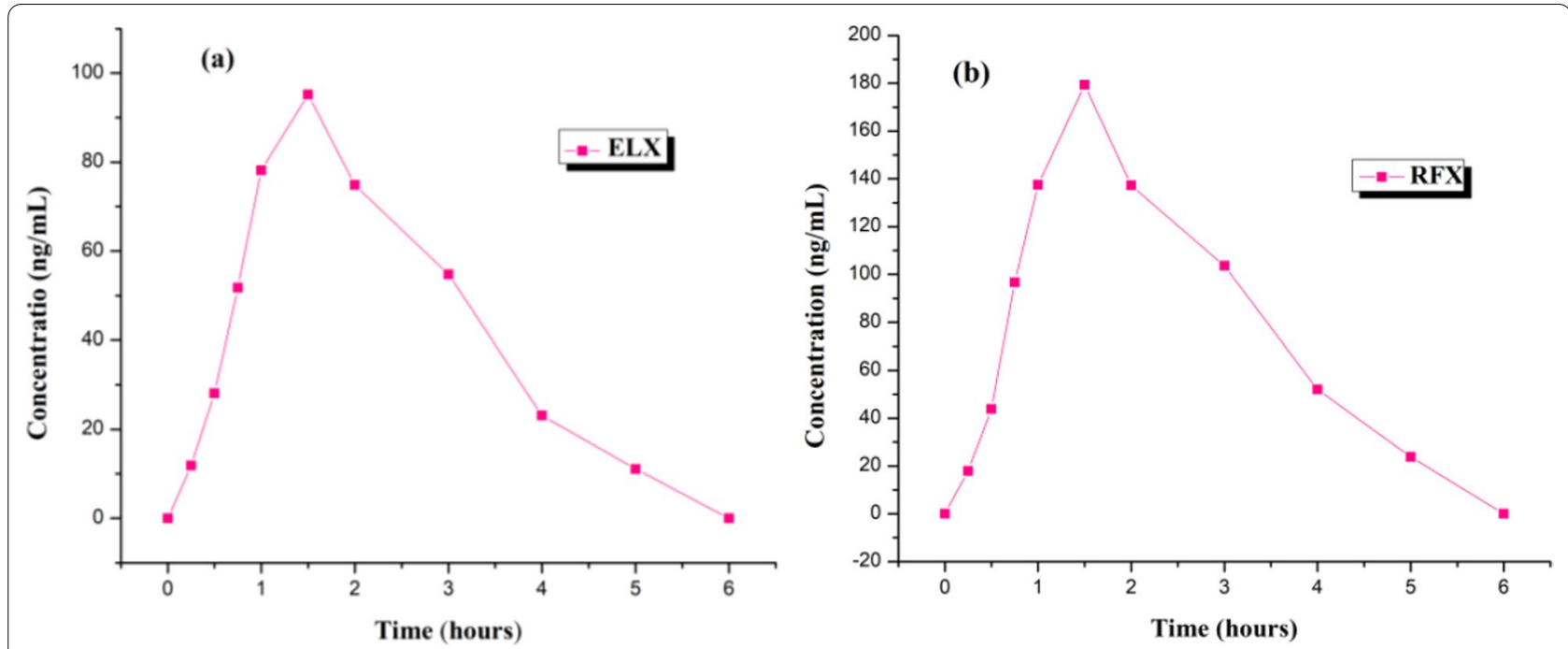

Fig. 3 The mean plasma concentration-time curve of a ELX $(0.416 \mathrm{mg} / \mathrm{kg})$, b RFX $(0.832 \mathrm{mg} / \mathrm{kg})$ in rats

Table 1 Intra- and Inter-day accuracy and precision results for ELX and RFX

\begin{tabular}{|c|c|c|c|c|c|c|c|}
\hline \multirow[t]{2}{*}{ Analytes } & \multirow{2}{*}{$\begin{array}{l}\text { Concentration level } \\
\left(\mathrm{ng} \mathrm{mL}^{-1}\right)\end{array}$} & \multicolumn{3}{|l|}{ Intra-day $(n=6)$} & \multicolumn{3}{|l|}{ Inter-day $(n=18)$} \\
\hline & & $\begin{array}{l}\text { Mean found conc. } \\
\text { (ng mL } \mathrm{mL}^{-1} \text { ) }\end{array}$ & CV (\%) & Accuracy (\%) & $\begin{array}{l}\text { Mean found conc. } \\
\text { (ng mL } \mathrm{mL}^{-1} \text { ) }\end{array}$ & CV (\%) & Accuracy (\%) \\
\hline \multirow[t]{4}{*}{ ELX } & LLOQ (5.0) & $5.02 \pm 0.023$ & 0.465 & 99.17 & $5.04 \pm 0.036$ & 0.717 & 99.6 \\
\hline & LQC (50.0) & $50.19 \pm 0.207$ & 0.413 & 99.65 & $50.43 \pm 0.50$ & 1.00 & 100.13 \\
\hline & MQC (100.0) & $99.89 \pm 0.134$ & 0.134 & 99.72 & $99.78 \pm 0.143$ & 0.144 & 99.6 \\
\hline & HQC (150.0) & $149.91 \pm 0.311$ & 0.207 & 99.68 & $149.94 \pm 0.637$ & 0.425 & 99.71 \\
\hline \multirow[t]{4}{*}{ RFX } & LLOQ (10.0) & $10.19 \pm 0.138$ & 1.358 & 99.42 & $10.18 \pm 0.12$ & 1.186 & 99.39 \\
\hline & LQC (100.0) & $100.36 \pm 0.148$ & 0.147 & 100.2 & $100.42 \pm 0.131$ & 0.130 & 100.2 \\
\hline & MQC (200.0) & $200.21 \pm 0.077$ & 0.038 & 100.0 & $200.23 \pm 0.143$ & 0.071 & 100.0 \\
\hline & HQC (300.0) & $302.16 \pm 2.457$ & 0.813 & 100.16 & $300.16 \pm 2.157$ & 0.714 & 100.61 \\
\hline
\end{tabular}

Table 2 Extraction recovery results for ELX and RFX

\begin{tabular}{|c|c|c|c|c|c|}
\hline \multirow[t]{2}{*}{ Analytes } & \multirow{2}{*}{$\begin{array}{l}\text { Spiked conc.level (ng } \\
\mathrm{mL}^{-1} \text { ) }\end{array}$} & \multicolumn{2}{|c|}{ Area response $(n=6)$} & \multirow[t]{2}{*}{ Extraction recovery (\%) } & \multirow[t]{2}{*}{ CV (\%) } \\
\hline & & $\begin{array}{l}\text { Extracted mean } \\
\text { response }\end{array}$ & $\begin{array}{l}\text { Post extracted mean } \\
\text { response }\end{array}$ & & \\
\hline \multirow[t]{3}{*}{ ELX } & LQC (50.0) & 65,540 & 67,563 & 97.0 & 0.68 \\
\hline & MQC (100.0) & 130,424 & 142,522 & 91.5 & 0.16 \\
\hline & HQC (150.0) & 195,784 & 208,552 & 93.8 & 0.31 \\
\hline \multirow[t]{3}{*}{ RFX } & LQC (100.0) & 120,553 & 122,549 & 98.3 & 0.17 \\
\hline & MQC (200.0) & 240,481 & 262,371 & 91.6 & 0.13 \\
\hline & HQC (300.0) & 362,942 & 380,569 & 95.3 & 0.83 \\
\hline
\end{tabular}

plasma sample were stable at $10^{\circ} \mathrm{C}$ for $24 \mathrm{~h}$. In the study of dry extract, the drugs were found to be stable at $10^{\circ} \mathrm{C}$ for $18 \mathrm{~h}$. In the study of freeze-thaw stability, frozen samples were found to be stable in three freeze-thaw cycles from $-80{ }^{\circ} \mathrm{C}$ to room temperature. The long-term stability test revealed that the analytes retained their stability for up to 28 days when stored at $-80^{\circ} \mathrm{C}$. The acceptance criteria for accuracy were found to be within a range of 
Table 3 Matrix effect results for ELX and RFX

\begin{tabular}{|c|c|c|c|c|c|c|c|c|}
\hline \multirow[t]{3}{*}{ Analytes } & \multicolumn{4}{|c|}{ Area response $(n=6)$} & \multirow{2}{*}{\multicolumn{2}{|c|}{ Matrix factor }} & \multirow{2}{*}{\multicolumn{2}{|c|}{ CV (\%) }} \\
\hline & \multicolumn{2}{|c|}{ Post extracted mean response } & \multicolumn{2}{|c|}{ Neat mean response } & & & & \\
\hline & LQC & HQC & LQC & HQC & LQC & HQC & LQC & HQC \\
\hline ELX & 65,540 & 195,784 & 67,563 & 208,552 & 0.97 & 0.93 & 0.68 & 0.32 \\
\hline RFX & 120,553 & 362,942 & 122,549 & 380,569 & 0.98 & 0.95 & 0.18 & 0.83 \\
\hline
\end{tabular}

Table 4 The stability study of ELX and RFX under storage condition in rat plasma

\begin{tabular}{|c|c|c|c|c|c|c|c|}
\hline \multirow[t]{2}{*}{ Storage condition } & \multirow[t]{2}{*}{ Conc. level } & \multicolumn{3}{|l|}{ ELX } & \multicolumn{3}{|l|}{ RFX } \\
\hline & & $\begin{array}{l}\text { Concentration } \\
\left(\mathrm{ng} \mathrm{mL}^{-1}\right)\end{array}$ & CV (\%) & Accuracy (\%) & $\begin{array}{l}\text { Concentration } \\
\left(\mathrm{ng} \mathrm{mL}^{-1}\right)\end{array}$ & CV (\%) & Accuracy (\%) \\
\hline \multirow[t]{2}{*}{ Bench top ( $6 \mathrm{~h}$ at RT) } & LQC & 50.0 & 0.41 & 97.0 & 100.15 & 0.14 & 98.3 \\
\hline & HQC & 150.0 & 0.1 & 93.7 & 300.3 & 0.04 & 94.6 \\
\hline \multirow[t]{2}{*}{ Autosampler $\left(24 \mathrm{~h}\right.$ at $\left.10^{\circ} \mathrm{C}\right)$} & LQC & 50.0 & 0.54 & 96.7 & 100.15 & 0.07 & 98.5 \\
\hline & HQC & 150.0 & 0.09 & 93.7 & 300.3 & 0.04 & 94.7 \\
\hline \multirow[t]{2}{*}{ Three freeze-thaw cycles $\left(-80^{\circ} \mathrm{C}\right.$ to $\left.\mathrm{RT}\right)$} & LQC & 50.0 & 0.39 & 96.6 & 100.15 & 0.32 & 98.4 \\
\hline & HQC & 150.0 & 0.1 & 93.7 & 300.3 & 0.08 & 94.7 \\
\hline \multirow[t]{2}{*}{ Long term ( 28 days at $-80^{\circ} \mathrm{C}$ ) } & LQC & 50.0 & 0.43 & 81.7 & 100.15 & 1.03 & 84.3 \\
\hline & HQC & 150.0 & 0.2 & 74.3 & 300.3 & 0.57 & 74.9 \\
\hline \multirow[t]{2}{*}{ Dry extract $\left(18 \mathrm{~h}\right.$ at $\left.10^{\circ} \mathrm{C}\right)$} & LQC & 50.0 & 0.61 & 97.0 & 100.15 & 1.92 & 100.9 \\
\hline & $\mathrm{HQC}$ & 150.0 & 0.98 & 93.6 & 300.3 & 0.62 & 95.9 \\
\hline
\end{tabular}

$85-115 \%$ and the precision $\leq 15 \%$ of the $\mathrm{CV}$. The results are shown in Table 4.

\section{Dilution integrity}

The integrity of dilution was assessed by measuring the concentration of each drug in rat plasma by twofold dilution with a blank matrix. The precision expressed as \% CV was found to be 1.08 and 0.65 for ELX and RFX and accuracy was found to be $97.5 \%$ and $100.8 \%$ for ELX and RFX, respectively. By analyzing the results, it can be inferred that the dilution of the samples in the rat plasma with blank plasma has caused no effect on the precision and accuracy of the procedure.

\section{A pharmacokinetic study in rats}

The validated analytical method was successfully applied to the assay of plasma samples collected from healthy rats after oral administration of $0.416 \mathrm{mg} / \mathrm{kg}$ and $0.832 \mathrm{mg} /$ $\mathrm{kg}$ for ELX and RFX, respectively. Figure 3 shows the mean plasma concentration vs time curves for ELX and RFX. Table 5 consists of the pharmacokinetic parameters namely, maximum plasma concentration $\left(C_{\max }\right)$, time of maximum plasma concentration $\left(T_{\max }\right)$, half-life $\left(t_{1 / 2}\right)$, the area under the concentration-time curve $0 \mathrm{~h}$ to infinity $\left(\mathrm{AUC}_{0-\infty}\right)$, and the area under the concentration-time
Table 5 Pharmacokinetic parameters

\begin{tabular}{lll}
\hline Parameter & Analytes & \\
\cline { 2 - 3 } & RFX & ELX \\
\hline$t_{1 / 2}(\mathrm{~h})$ & 5.0 & 5.0 \\
$t_{\max }(\mathrm{h})$ & 1.5 & 1.5 \\
$C_{\max }(\mathrm{ng} / \mathrm{mL})$ & 95.2 & 179.3 \\
$\mathrm{AUC}_{0-t}(\mathrm{ng} \mathrm{h} / \mathrm{mL})$ & 245 & 463 \\
$\mathrm{AUC}_{0-\infty}(\mathrm{ng} \mathrm{h} / \mathrm{mL})$ & 245 & 463 \\
$\mathrm{AUC}_{t-\infty}(\mathrm{ng} \mathrm{h} / \mathrm{mL})$ & 11.9 & 23.8 \\
\hline
\end{tabular}

curve $0 \mathrm{~h}$ to time ' $t$ ' $\left(\mathrm{AUC}_{0-t}\right)$ which were calculated by using WinNonlin software.

\section{Discussion}

From the literature reports, no analytical approach for the simultaneous determination of eluxadoline and rifaximin in rat plasma has been described. Currently, there are few literature reports on the methods for the individual determination of eluxadoline have been reported [10-13] and for the individual estimation of rifaximin have been reported [14-20]. Even though these techniques have attained the requisite sensitivity and application, some of them require a considerable volume of plasma, many 
of them adopt a tedious extraction procedure, and others are either expensive or unavailable in most laboratories. Whereas, the method used in the present study, HPLCPDA has numerous advantages such as good separation, high sensitivity, outstanding specificity, and low cost as compared to the methods reported earlier.

The developed method has been validated as per the USFDA guidelines for all the parameters. The developed method has good linear with correlation coefficient values of 0.9999 for ELX and 0.9998 for RFX indicates a good correlation over the linearity range. The precision and accuracy of the method were determined through the percentage of coefficient of variation (\% CV) and percentage recovery. The acceptance criteria for accuracy within a range of $85-115 \%$ and the precision within $15 \%$ of the CV (Table 1). The LLOQ values of the proposed method represents that the method is highly sensitive (Additional file 1: Table S1). The extraction recovery of the spiked ELX and RFX were found to be in the ranges from 97.0 to 91.5 and 98.3 to 91.6 , which represents that the proposed method has adequate accuracy as per FDA guidelines. The method was successfully applied to pharmacokinetic study of ELX and RFX in rat plasma.

\section{Conclusions}

In the present research work, we have successfully developed an HPLC-PDA method for the determination of ELX and RFX in Wistar rat plasma and validated the method. This method developed in the present study has a benefit of being simple and cost-effective liquid-liquid extraction for sample pre-treatment along with a reduced chromatography acquisition time, and the separation of analytes possible with an isocratic mode with a mobile phase (HPLC grade acetonitrile and aqueous solution of TEA, pH 2.5). The lower limit of quantification for ELX was found to be $5.0 \mathrm{ng} \mathrm{mL} \mathrm{m}^{-1}$, and for RFX was found to be $10.0 \mathrm{ng} \mathrm{mL}{ }^{-1}$. The approach was fully validated to meet the USFDA guidelines for bioanalytical method validation in terms of accuracy, precision, and stability. The presented approach could be beneficial for the determination of ELX and RFX in rat plasma, according to validation parameters. This method was also used to study the pharmacokinetics of ELX and RFX in rats.

\footnotetext{
Abbreviations

HPLC-PDA: High-performance liquid chromatography-photodiode array; LLOQ: Lower limits of quantification; ULOQ: Upper limits of quantification; ELX: Eluxadoline; RFX: Rifaximin; IS: Internal standard; USFDA: United States Food and Drug Administration; IBS: Irritable bowel syndrome; SPE: Solid phase extraction; ACN: Acetonitrile; OPA: Orthophosphoric acid; TEA: Triethylamine; LQC: Lower quality control; MQC: Medium quality control; HQC: Higher quality control; CV: Coefficient of variation; AUC: Area under the curve; HR-MS/MS: High-resolution tandem mass spectrometry.
}

\section{Supplementary Information}

The online version contains supplementary material available at https://doi. org/10.1186/s43094-022-00403-x.

Additional file 1. Electronic Supplementary Information.

\section{Acknowledgements}

The authors are grateful to National Institute of Technology Warangal, India for providing the research facilities.

\section{Authors' contributions}

VK done the experiment with interpretation of the data and major contribution in preparing the draft version of manuscript. BP has also analyzed the data and discussions in the analysis. MR and RC has visualized and supervised study, critically reviewed the data and supported for writing the manuscript. All the authors have read and approved the manuscript prior to the submission.

\section{Funding}

Author RC is grateful to the Department of Science and Technology (DST, CRG/2018/002661), RC and MR are grateful to National Institute of Technology Warangal (NITW) for the Research Seed Money (P1078 Plan Gen.-RSM and P1082 Plan Gen.-RSM respectively), and DST-FIST grant, SR/FST/CSII/2018/65 awarded to Department of Chemistry, NITW for the financial support of this work. VRK is grateful to NITW for Senior Research Fellowship.

\section{Availability of data and materials}

All data and materials are available upon request.

\section{Declarations}

\section{Ethics approval and consent to participate}

Animal house facility were provided by Manisha Laboratories, Mumbai, Maharashtra, India. Animal experiments and study protocols are approved by the Institutional Animal Ethics Committee with reference number (Registration No.: 1074/PO/Re/S/05/CPCSEA), under CPCSEA, Delhi, India. All institutional and national guidelines for the care and use of laboratory animals were followed.

\section{Consent for publication}

Not applicable.

\section{Competing interests}

The authors declare that they have no competing interests.

Received: 21 August 2021 Accepted: 13 January 2022

Published online: 25 January 2022

References

1. Assessment report Truberzi (Eluxadoline) (2016) Committee for medicinal products for human use. European Medicines Agency (EMA/549473/2016). 21: http://www.ema.europa.eu/docs/en GB/ document library/EPAR Public assessment report/human/004098/ WC500213370.pdf. Accessed 10 September 2017

2. Fichna J, Sobolewska-Wlodarczyk A, Wlodarczyk M, Storr M (2016) Clinical potential of eluxadoline in the treatment of diarrhea-predominant irritable bowel syndrome. Ther Clin Risk Manag 11:771. https://doi.org/10. 2147/TCRM.S83722

3. Wade P, Palmer J, McKenney S, Kenigs V, Chevalier K, Moore B, Mabus J, Saunders P, Wallace N, Schneider C, Kimball E, Breslin H, He W, Hornby $P$ (2012) Modulation of gastrointestinal function by MuDelta, a mixed $\mu$ opioid receptor agonist/ $\mu$ opioid receptor antagonist. Br J Pharmacol 167:1111-1125. https://doi.org/10.1111/j.1476-5381.2012.02068.x

4. Dove LS, Lembo A, Randall CW, Fogel R, Andrae D, Davenport JM, Mclntyre G, Almenoff JS, Covington PS (2013) Eluxadoline benefits patients with irritable bowel syndrome with Diarrhea in a phase 2 study. 
Gastroenterology 145:329-338. https://doi.org/10.1053/j.gastro.2013.04. 006

5. Özdener AE, Rivkin A (2017) Eluxadoline in the treatment of diarrhea-predominant irritable bowel syndrome. Drug Des Devel Ther 11:2827-2840. https://doi.org/10.2147/DDDT.S127405

6. Levy-Cooperman N, McIntyre G, Bonifacio L, McDonnell M, Davenport JM, Covington PS, Dove LS, Sellers EM (2016) abuse potential and pharmacodynamic characteristics of oral and intranasal eluxadoline, a mixed $\mu$ - and $\mathrm{k}$-opioid receptor agonist and $\delta$-opioid receptor antagonist. J Pharmacol Exp Ther 359:471-481. https://doi.org/10.1124/jpet.116. 236547

7. Lembo AJ, Lacy BE, Zuckerman MJ, Schey R, Dove LS, Andrae DA, Davenport JM, McIntyre G, Lopez R, Turner L, Covington PS (2016) Eluxadoline for irritable bowel syndrome with Diarrhea. N Engl J Med 374:242-253. https://doi.org/10.1056/NEJMoa1505180

8. Lacy BE, Harris LA, Chang L, Lucak S, Gutman C, Dove LS, Covington PS, Lembo A (2019) Impact of patient and disease characteristics on the efficacy and safety of eluxadoline for IBS-D: a subgroup analysis of phase III trials. Therap Adv Gastroenterol 12:175628481984129. https://doi.org/ $10.1177 / 1756284819841290$

9. Brenner DM, Sayuk GS, Gutman CR, Jo E, Elmes SJR, Liu LWC, Cash BD (2019) Efficacy and safety of eluxadoline in patients with irritable bowel syndrome with diarrhea who report inadequate symptom control with loperamide: RELIEF phase 4 study. Am J Gastroenterol 114:1502-1511. https://doi.org/10.14309/ajg.0000000000000327

10. Iqbal M, Ezzeldin E, Al-Rashood KA, Al-Shdefat R, Anwer MK (2018) High throughput $\mu$-SPE based elution coupled with UPLC-MS/MS for determination of eluxadoline in plasma sample: application in pharmacokinetic characterization of PLGA nanoparticle formulations in rats. J Pharm Biomed Anal 149:172-178. https://doi.org/10.1016/j.jpba.2017.10.024

11. Dodda S, Makula A, Polagani SR, Kandhagatla RN (2019) High sensitive LC-MS/MS method for estimation of eluxadoline in human plasma and its application to pharmacokinetic study. J Pharm Biomed Anal 165:65-72. https://doi.org/10.1016/j.jpba.2018.11.056

12. Pakalapati S, Rumalla CS, Gudapati AR, Korupolu RB, Gajbhiye SB, Kaliyaperumal M (2020) A novel RP-HPLC method development and validation for determination and estimation of eluxadoline drug with its impurities. SN Appl Sci 2:1036. https://doi.org/10.1007/s42452-020-2834-9

13. Vajjha S, Bommuluri V, Rumalla CS, Kaliyaperumal M, Korupolu RB, Chopella V (2020) Degradation behavior of eluxadoline under stress conditions: structural interpretation of novel degradants using high resolution mass spectrometry and nuclear magnetic resonance. Mater Today Proc 33:2092-2106. https://doi.org/10.1016/j.matpr.2020.02.135

14. Mathrusri Annapurna M, Sai Pavan Kumar B, Venkatesh B, Raj Prakash J (2012) Development and validation of a stability-indicating high performance liquid chromatographic assay for rifaximin in bulk and pharmaceutical dosage forms. Drug Invent Today 4:430-434

15. Hossain MA, Pervin R, Park N-H, Kang JW, Lee KJ, Suh JW, Park SC (2018) Development of a simple and sensitive HPLC method for the determination of rifaximin in serum and its application. Indian J Pharm Sci. https:// doi.org/10.4172/pharmaceutical-sciences.1000462

16. Rao RN, Shinde DD, Agawane SB (2009) Rapid determination of rifaximin in rat serum and urine by direct injection on to a shielded hydrophobic stationary phase by HPLC. Biomed Chromatogr 23:563-567. https://doi. org/10.1002/bmc.1149

17. Nageswara Rao R, Mastan Vali R, A. Vara Prasada Rao, (2012) Determination of rifaximin in rat serum by ionic liquid based dispersive liquid-liquid microextraction combined with RP-HPLC. J Sep Sci 35:1945-1952. https:// doi.org/10.1002/jssc.201200202

18. Zhang X, Duan J, Li K, Zhou L, Zhai S (2007) Sensitive quantification of rifaximin in human plasma by liquid chromatography-tandem mass spectrometry. J Chromatogr B 850:348-355. https://doi.org/10.1016/j. jchromb.2006.12.001

19. Nageswara Rao R, Vali RM, Ramachandra B, Maurya PK (2011) Rapid determination of rifaximin on dried blood spots by LC-ESI-MS. Biomed Chromatogr 25:1201-1207. https://doi.org/10.1002/bmc.1591

20. Rao RN, Vali RM, Shinde DD (2009) On-line 2D-LC-ESI/MS/MS determination of rifaximin in rat serum. Biomed Chromatogr 23:1145-1150. https:// doi.org/10.1002/bmc.1236

21. Nagaraju K, Chowdary YA, Rao MVB (2021) Development and validation of bexarote by bioanalytical methods using liquid chromatography-tandem mass spectroscopy (LC-MS/MS). Future J Pharm Sci 7(28):1-10. https:// doi.org/10.1186/s43094-020-00155-6

22. Kachave RN, Yelmame SS, Mundhe AG (2021) Quantitative estimation of cilnidipine and valsartan in rat plasma by RP-HPLC: its pharmacokinetic application. Future J Pharm Sci 7(7):1-7. https://doi.org/10.1186/ s43094-020-00153-8

23. Rao KP, Laa N, Babu K, Koganti B, Palakeeti KSV, Srinivas, (2021) Related substances method development and validation of an LCMS/MS method for quantification of selexipag and its related impurities in rat plasma and its application to pharmacokinetic studies. SN Appl Sci 3(321):1-12. https://doi.org/10.1007/s42452-021-04219-x

24. Food and Drug Administration (2013) US Department of Health and Human Services, Center for Drug Evaluation and Research, Center for Vetenary Medicine, Guidance for Industry Bioanalytical Method Validation Guidance for Industry Bioanalytical Method Validation, Draft Version NonBinding Recomm. by FDA. Rev. 1: http://www.fda.gov/downloads/drugs/ guidancecomplianceregulatoryinformation/guidances/ucm368107.pdf

\section{Publisher's Note}

Springer Nature remains neutral with regard to jurisdictional claims in published maps and institutional affiliations.

\section{Submit your manuscript to a SpringerOpen ${ }^{\circ}$ journal and benefit from:}

- Convenient online submission

- Rigorous peer review

- Open access: articles freely available online

- High visibility within the field

- Retaining the copyright to your article

Submit your next manuscript at $\boldsymbol{\nabla}$ springeropen.com 